\title{
A BRIEF OVERVIEW OF THE HISTORY OF FEB
}

\section{Željko Sirk*}

The First World War, the collapse and disintegration of the Austro-Hungarian Empire, and the creation of new states interrupted the already expensive and difficult to access higher education opportunities for Croatian youth in the old university centers of the Monarchy. Therefore, barely a month and a half after the creation of the new state, the SCS Board of Commissioners (Provisional Government) in Zagreb issued an order on the establishment of the Technical High School, the Faculty of Agriculture and Forestry and the Faculty of Veterinary Medicine (published in the Official Gazette on December 18, 1918). The Technical High School had six technical departments, and three courses: Geodetic Course, the Insurance Technique Course, and the Education Course for Teachers in Higher Commercial Schools. The first students of the Education Course for Teachers in Higher Commercial Schools at the Royal Technical High School were invited to enroll "in the academic year 1919/20" by an advertisement published in the Official Gazette No. 152 of October 18, 1919, announcing the lectures starting on November 3, 1919. However, as it turned out from the beginning that such an organization of studies could not function well, a decision was brought before the end of the school year to separate the Course... from the Technical High School and to transform it into an independent higher education institution. By the Royal Decree establishing the High School of Commerce and Transport in Zagreb until its later constitutional establishment, the High School ... began operating on July 1, 1920. The HSCT, as well as its successor, the Economic and Commercial High School, were independent higher education institutions throughout their existence organized outside the University of Zagreb. Classes at the High School of Commerce and Transport lasted 3 years (6 semesters), and for the entire period of its existence (from the academic year 1920-1921 to the academic year 19241925 ) the same curriculum was used (lecture order), which was amended only according to the expressed needs.

*Željko Sirk, University of Zagreb Faculty of Economics \& Business, Croatia; zsirk@net.efzg.hr. 
The High School of Commerce and Transport has faced three main problems since its inception: an enormous number of students (1125 students in 1923/1924), an overloaded schedule, and the lack of a single facility for teaching. Such an unsustainable situation could not be solved by this higher education institution on its own, even relying on King Alexander and Queen Mary Endowment, established in 1922. Fortunately, the situation changed when, in November 1925, Stjepan Radić entered the government of the Kingdom of Yugoslavia as Minister of Education. At his initiative, it was legalized by Art. 11 of the Financial Law of November 30, 1925 ("Official Gazette" No. 276 - Belgrade; and "Official Gazette” No. 285 - Zagreb, of December 1, 1925) authorization that through a partial amendment of Art. 3. of the legal decree of 17 June 1920 on the organization of the High School of Trade and Transport this school is transformed into the Economic and Commercial High School, with the legal status of a university faculty and extended to four academic years, and that everything necessary was determined at the suggestion of the Council of Professors. On the basis of this authorization, the Professors' council, with the approval of Minister Stjepan Radić, submitted to King Alexander for confirmation the legal decree of December 23, 1925, on the organization of the Economic and Commercial High School (published in the Official Gazette no. 25, Belgrade, February 4, 1926; Gazette No. 12, Zagreb, January $16,1926)$. Thus, with the convening of the 1st extraordinary session of the Professors' Council of the Economic and Commercial High School (ECHS) in Zagreb on January 2, 1926, it formally began its work.

Less than two years after the formation of the ECHS, this higher education institution was in danger of being shut down. Under the pretext of savings and lack of budget funds, the Ministry of Education is trying to abolish the Faculty of Medicine, and then at the end of the same year the agricultural department of the Faculty of Agriculture and Forestry, University of Zagreb. It went on, so the new draft law on universities provided for the abolition of the Faculty of Veterinary Medicine or its transformation into a high school without a university rank. By the same draft law, ECHS was to lose its faculty rank, received back in 1925 . After fierce protests by the entire Croatian public in the autumn of 1927, the Yugoslav authorities gave up the idea of these abolitions.

In January 1927 (just before the crisis over the abolition of university faculty status broke out), King Alexander and Queen Maria Endowment, founded in 1922 by Croatian chambers of commerce, monetary institutions, stock exchanges, and associations of merchants and industrialists to construct the ECHS building was activated. On the construction lot donated by the City of Zagreb (at the corner of today's Zvonimirova and Bauerova streets), the ECHS building was erected and moved in within a year and a half, in Novem- 
ber 1928. Then in 1929-1931. another building was built in Bauerova Street intended for rental housing for the maintenance of the faculty building.

The question of the status and even the survival of the ECHS in Zagreb was in some way brought into question in 1937 by the establishment of the Economic and Commercial High School in Belgrade. By the Financial Law for 1936/1937 prescribed by the Ministry of Education of the Kingdom of Yugoslavia a decree of March 31, 1937, with the legal force on the establishment of the ECHS in Belgrade was issued. According to these stipulations, the newly established high school had the legal status of a university faculty, but its legal regulations were not corresponding to that. Therefore, the obvious intention of the establishment was to "narrow down" the autonomy of the Zagreb ECHS, as both schools were to enjoy the same status, so as soon as the ECHS began operating in Belgrade, the issue of its reorganization was raised. However, as the organization of the ECHS in Zagreb had already been once and for all regulated by a decree of 23 December 1925, it was only possible to regulate the legal regulations on the ECHS in Belgrade. Efforts on the change of the inadequate legal stipulations brought results only in 1939. Then, with the amendment of the Financial law of March 25, 1939, a provision was legalized, according to which the Ministry of Education was authorized to pass a decree with legal force on the ECHS in Belgrade and Zagreb, and on that occasion to equalize the organization of these high schools on the basis of autonomy, which belongs to the universities. This created the legal conditions for the reorganization of the Belgrade ECHS, and the status of the Zagreb ECHS was not curtailed, because all the novelties, as far as Zagreb was concerned, had already been regulated by (Radić's) legal decree of 1925 .

It soon became clear that the newly built corner house was too small in the part intended for teaching, so the Rector's Office and the Council of Professors launched an action to build the building, which would meet all the needs of modern teaching. With the support of the Chamber of Commerce, they managed to raise a loan of 10,000,000 dinars in 1939, from which a large building plot $(\approx 172,933 \mathrm{~m} 2)$ was bought in Svetice in 1940 . WWII stopped construction, so it continued only in 1947. With the collapse of the Kingdom of Yugoslavia and the establishment of the Independent State of Croatia, ECHS continues to operate under the name of the Croatian High School of Economics and Commerce, although in difficult war conditions, because the German army moved into the part of the building.

With the collapse of the Independent State of Croatia, the Germans left the undamaged faculty building, so in the fall of 1945, it was possible for the reestablished Economic and Commercial High School to continue operating under the old name. In order to avoid political games over the status of ECHS, in 
1947 it became part of the University of Zagreb as the Faculty of Economics. Since 1948, the construction of the building in Svetice has continued, which, although still not completely finished, moved in in 1952. Throughout the war and post-war period, and even in the first year of the Faculty of Economics, pre-war curricula were used, modified according to socio-political changes. In ac. year 1947/1948, new curricula were adopted, which reduced the number of teaching disciplines to an average of 10 per year, abolished three professional (state) exams, and all exams were taken individually. Teaching disciplines that were not necessary for the economic profile have been removed from the curriculum, and some new ideologically and politically adjusted disciplines have been introduced. This curriculum was more or less the basis on which major or minor changes were made until 1965 when the unified curriculum for all students was definitely abandoned.

The recovery and development of the Croatian economy created the need for adapted education of newly appointed executive personnel in companies, so in 1956 the authorities of the People's Republic of Croatia established the High School of Economics (HSE). The structure of students has changed over the years, and the curricula adapted to that have become more and more similar to those of the Faculty of Economics, which in 1968 led to the integration with the Faculty of Economics into the Faculty of Economic Sciences (FES).

As early as 1960, the Faculty of Economics founded the Center of the Faculty of Economics in Varaždin, as the first higher education institution in northwestern Croatia after more than two centuries. The center operated until March 31, 1969, when it became an independent institution under the name of the Higher School of Economics in Varaždin and later grew into the Faculty of Organization and Informatics. The successful practice of establishing study centers/departments continued in the autumn of 1970 with the opening of the Department of Tourism and Foreign Trade in Dubrovnik. In April 1971, the Department of Finance and Organization of FES was established in Split, joined by the Institute for Maritime, Tourist, and Coastal Economy. Such a large territorially dispersed higher education organization had a hard time functioning, so as early as 1974 there was a separation of departments in Split and Dubrovnik, which after the founding of the University of Split became independent faculties. Thus, out of four departments (or according to the then organizational and legal norm: OOUR) of FES, only the OOUR Faculty of Economics in Zagreb remained, which returned the old name to this higher education institution.

Just as a few years earlier the solution for the education of managers in companies was found in the establishment of HSE, so the growing need for professional staff in foreign trade resulted in 1961 in the establishment of a two- 
year Higher School of Foreign Trade, which changed the name in 1964 to the College of Foreign Trade (CFT). In the academic year 1966/1967 College ... grows into a High School of Foreign Trade (HSFT) with a three-year study. In 1974, the High School of Foreign Trade upgraded to a four-year study changed its name to the Faculty of Foreign Trade and became part of the University of Zagreb as a university faculty. Initially, two basic fields were the backbone of the program structure of the Faculty of Foreign Trade, namely the Department of Foreign Trade and the Department of Internal Trade, both as a two-year (for higher education) and four-year study (for high education). Very quickly, the development of transport, production, and the tourist economy influenced the introduction of additional directions, especially after the Higher Hotel School was annexed to the FVT in January 1979. Thus, the fields of Transport (as a two-year and four-year study), Catering and Tourism (with specializations Tourism, as a two-year and four-year study and Hotel Management, as a twoyear study), Exchange and Market (with a specialization in Economic Propaganda as a two-year study) and Customs (as a two-year study for work in the customs service) were introduced. The growing similarity and overlap of curricula led in the middle of 1982 to the logical merger (integration) of the Faculty of Foreign Trade with the Faculty of Economics in Zagreb.

After the integration, classes took place in three buildings on J. F. Kennedy Square 6 (Faculty of Economics), 7 (former HSE building), and 8 (former FFT building). The curricula of the Faculty of Economics and the former Faculty of Foreign Trade were not changed for a vile. In 1985, on the eve of the Universiade, buildings at no. 7 and 8, went on sale, while all teaching and administrative staff moved temporarily to the old Faculty of Economics building (No.6). This sale partially covered the cost of building extension with a sports hall and the majority of investment was covered from the Universiade budget. After less than two years, a new reorganization followed by moving into a newly extended part of the building, which enabled teaching and other faculty activities to take place in normal conditions. The cornerstone for the extension was laid on July 27, 1985, and for the opening of the Universiade (July 9-18, 1987), not only was the sports hall in full function, but other parts were completed and moved in, so that the FISU Summer Universiade Conference was held from July 10 to 12,1987 in the FEB Congress Hall. This conference, on the other hand, was only the first in a series of large scientific gatherings to be organized at the FEB by the end of the 1980s, and this practice continued after Croatia's independence, even during the difficult war years, contributing greatly to international recognition of the Faculty and Croatia.

After the independence of Croatia and the ensuing war, in the second half of the 1990s, it was of special importance to adopt a new curriculum from which 
ideology was banished, the study divided into the study of economics and business economics, and harmonized with the programs of the most prestigious economic schools of the countries of the developed market economy. With the Bologna Declaration of EU Ministers in June 1999, the process of creating a single European higher education system began, which was soon joined by the Faculty of Economics \& Business. Faculty of Economics \& Business has been organized according to the Bologna principles since the academic year 2005/2006 (university undergraduate studies, university graduate studies, postgraduate studies, and professional studies). From the academic year 2015/2016 integrated university undergraduate and graduate studies (5-year) are gradually being introduced at the Faculty. Today, at the Faculty, teaching is conducted in the field of economics and business economics in Croatian and English, and at the professional level in Croatian (as a full-time and parttime study). The integrated undergraduate and graduate university studies in Economics and Business Economics last ten semesters (with eight majors: Analysis and Business Planning, Finance, Marketing, Management Informatics, Management, Accounting and Auditing, Trade and International Business and Tourism). Undergraduate university studies last eight semesters and are conducted in English only (Bachelor's Degree in Business and Bachelor's Degree in Economics). The graduate university study of Business Economics and the graduate university study of Economics lasted two semesters, but in the academic year 2018/2019 the last generation of students was enrolled, as the study was replaced by integrated undergraduate and graduate university studies. The graduate university study is also conducted in English and has two studies Graduate Study Program Master Degree in Economics and Graduate Study Program Master Degree in Business Economics, which is divided into four majors Master in Management, Master in Managerial Informatics, Master in Trade and International Business. The undergraduate professional study Business Economics lasts three years, i.e. six semesters, and has three majors: Accounting and Finance, Trade Business and Tourism Business. The graduate specialist professional studies in Entrepreneurship Economics and Energy and Environmental Economics last four semesters.

Study Bachelor's Degree in Business (BDiB) has an international accreditation of EPAS awarded by EFMD - Global Network, an international, non-profit organization, whose members are business schools and corporations, based in Brussels and with offices in Asia, Australia, and both Americas.

As of mid-2015, the Faculty of Economics \& Business entered the process of obtaining the second prestigious international accreditation of AACSB (The Association to Advance Collegiate Schools of Business), the oldest global accreditation body in the world for higher education institutions in the field 
of business economics. In July 2019, at the AACSB session, the Faculty of Economics \& Business - Zagreb was officially awarded AACSB accreditation. It was pointed out that the Faculty of Economics \& Business in Zagreb has fully met all the accreditation requirements of this external evaluation, and especially was emphasized the excellence in the quality of the educational process, quality of work and commitment of the Faculty translated into the strong mission, vision and strategy of the Faculty, teacher competence, internationalization Faculty on the basis of 6 study programs in English, cooperation agreements with about 140 foreign scientific institutions and professional organizations, a large number of foreign students and multicultural study experience. By all these Faculty has a strong impact on the economy and the wider community. This accreditation is especially important because the Faculty of Economics \& Business - Zagreb is the only university higher education institution in the Republic of Croatia that has been granted AACSB accreditation, which accredits the entire institution. In the world, only $5 \%$ of higher education institutions have AACSB accreditation in that sense.

The last two decades in Croatia have been marked by efforts to join the European Union, and when full membership was finally achieved in 2013, the process of not always easy integration continued, with the Faculty of Economics \& Business in Zagreb giving its contribution, primarily by continuing to organize a series major international conferences (such as the bi-annual An Enterprise Odyssey - since 2002), round tables and guest lectures, which were held or attended by, among others, Croatian presidents, ministers, domestic and foreign ambassadors, etc. With Croatia's accession to the EU, FEB uses new opportunities to invite not only economic experts but also administrative officials of the Union, enabling direct contact with our academic community and the general public thus providing "insider's view" in the work of the European Commission and the European Parliament. As early as February 2015, Mr. Jyrki Tapani Katainen, Vice-President of the European Commission and Commissioner for Jobs, Growth, Investment, and Competitiveness, gave a lecture on "Future of Europe". Shortly afterward, on December 1, 2016, the European Documentation Center (EDC) within the Library Documentation Center of the Faculty of Economics \& Business - Zagreb was inaugurated as a result of cooperation with the Representation of the European Commission in Croatia. Then, in co-organization with the EC Delegation to the Republic of Croatia, a series of events continued, of which at least once a year were visits and lectures by top European Commission officials: March 28, 2017 lecture and interview with Ms. Anna Cecilia Malmström, European Commission Commissioner for Trade; January 30, 2018 lecture and conversation with the Vice President of the European Commission for Energy Union Mr. Maroš Šefčovič; October 29, 2018, with the Vice President of the European Commis- 
sion for Euro and Social Dialogue, for Financial Stability, Financial Services and Capital Markets Union Mr. Valdis Dombrovskis and Minister of Finance Zdravko Marić. Finally, on May 8, 2019, the Prime Minister of the Republic of Croatia Andrej Plenković and Mr. Michel Bernard Barnier, the Chief Negotiator of the European Union for Brexit (Chief Negotiator - Task Force for the Preparation and Conduct of the Negotiations with the UK) participated in the Dialogue with Citizens. 